\title{
Protective Role of Natural and Semi-Synthetic Tocopherols on TNF $\alpha$-Induced ROS Production and ICAM-1 and Cl-2 Expression in HT29 Intestinal Epithelial Cells
}

\author{
Vladana Domazetovic ${ }^{1}\left(\mathbb{D}\right.$, Irene Falsetti ${ }^{1}$, Caterina Viglianisi ${ }^{2} \mathbb{D}$, Kristian Vasa ${ }^{2} \mathbb{D}$, Cinzia Aurilia ${ }^{1}$, Maria Stio ${ }^{1}$, \\ Stefano Menichetti ${ }^{2, *(D)}$ and Teresa Iantomasi ${ }^{1, *}$ \\ 1 Department of Biomedical, Experimental and Clinical Sciences "Mario Serio", University of Florence, \\ Viale Pieraccini, 6, 50134 Firenze, Italy; vladana.domazetovic@unifi.it (V.D.); irene.falsetti@unifi.it (I.F.); \\ aurilia.cinzia@gmail.com (C.A.); maria.stio@unifi.it (M.S.) \\ 2 Department of Chemistry "Ugo Schiff”, University of Florence, Via Della Lastruccia, 3-13, \\ 50019 Sesto Fiorentino (FI), Italy; caterina.viglianisi@unifi.it (C.V.); kristian.vasa@unifi.it (K.V.) \\ * Correspondence: stefano.menichetti@unifi.it (S.M.); teresa.iantomasi@unifi.it (T.I.); \\ Tel.: +39-055-4573535 (S.M.); +39-055-2758100 (T.I.)
}

Citation: Domazetovic, V.; Falsetti, I.; Viglianisi, C.; Vasa, K.; Aurilia, C.; Stio, M.; Menichetti, S.; Iantomasi, T. Protective Role of Natural and SemiSynthetic Tocopherols on TNF $\alpha$ Induced ROS Production and ICAM-1 and Cl-2 Expression in HT29 Intestinal Epithelial Cells. Antioxidants 2021, 10, 160. https://doi.org/10.3390/ antiox10020160

Received: 18 November 2020

Accepted: 19 January 2021

Published: 22 January 2021

Publisher's Note: MDPI stays neutral with regard to jurisdictional claims in published maps and institutional affiliations.

Copyright: (c) 2021 by the authors. Licensee MDPI, Basel, Switzerland. This article is an open access article distributed under the terms and conditions of the Creative Commons Attribution (CC BY) license (https:/ / creativecommons.org/licenses/by/ $4.0 /)$.

\begin{abstract}
Vitamin E, a fat-soluble compound, possesses both antioxidant and non-antioxidant properties. In this study we evaluated, in intestinal HT29 cells, the role of natural tocopherols, $\alpha$-Toc and $\delta$-Toc, and two semi-synthetic derivatives, namely bis- $\delta$-Toc sulfide $(\delta-T o c)_{2} \mathrm{~S}$ and bis- $\delta$ Toc disulfide ( $\delta$-Toc $)_{2} S_{2}$, on TNF $\alpha$-induced oxidative stress, and intercellular adhesion molecule-1 (ICAM-1) and claudin-2 (Cl-2) expression. The role of tocopherols was compared to that of $\mathrm{N}$ acetylcysteine (NAC), an antioxidant precursor of glutathione synthesis. The results show that all tocopherol containing derivatives used, prevented TNF $\alpha$-induced oxidative stress and the increase of ICAM-1 and Cl-2 expression, and that ( $\delta$-Toc $)_{2} S$ and $(\delta-T o c)_{2} S_{2}$ are more effective than $\delta$-Toc and $\alpha$-Toc. The beneficial effects demonstrated were due to tocopherol antioxidant properties, but suppression of $\mathrm{TNF} \alpha$-induced $\mathrm{Cl}-2$ expression seems not only to be related with antioxidant ability. Indeed, while ICAM-1 expression is strongly related to the intracellular redox state, $\mathrm{Cl}-2$ expression is $\mathrm{TNF} \alpha$-up-regulated by both redox and non-redox dependent mechanisms. Since ICAM- 1 and Cl-2 increase intestinal bowel diseases, and cause excessive recruitment of immune cells and alteration of the intestinal barrier, natural and, above all, semi-synthetic tocopherols may have a potential role as a therapeutic support against intestinal chronic inflammation, in which TNF $\alpha$ represents an important proinflammatory mediator.
\end{abstract}

Keywords: oxidative stress; natural and semi-synthetic tocopherols; tumor necrosis factor- $\alpha$ (TNF $\alpha$ ); intercellular adhesion molecule-1 (ICAM-1); claudin-2 (Cl-2)

\section{Introduction}

Vitamin E, the most important fat-soluble vitamin, is a mixture of four tocopherols (Toc) $\left(\alpha-, \beta-, \gamma_{-}\right.$, and $\left.\delta_{-T o c}\right)$ and four tocotrienols $\left(\alpha-, \beta-, \gamma_{-}^{-}\right.$, and $\delta$-tocotrienol), differing in the number and position of methyl groups on the chromanol ring [1], and the saturation of the aliphatic tail (Figure 1). As a matter of fact, $\alpha$-tocopherol $(\alpha-$ Toc) is the main component of natural vitamin $\mathrm{E}$, and is often indicated as vitamin E itself.

Dietary sources of vitamin $\mathrm{E}$ are fat-containing foods in which different tocopherols and tocotrienols are present in variable quantity [2]. However, daily foods, such as cheese, fruits, and eggs, also contain isoforms of vitamin E [3]. Vitamin E is considered a powerful antioxidant for its ability to scavenge radical oxygen species (ROS), and, due to its membrane localization, protects cell membranes from lipid peroxidation [4]. In fact, membrane phospholipids are targets easily exposed to oxidants, and the absence of vitamin E does not promote damage repair [2]. Oxidative stress is a key event involved in the onset and progression of the inflammatory response that characterizes pathologies 
such as cardiovascular diseases, type 2 diabetes mellitus, atherosclerosis, autoimmune diseases, and intestinal inflammatory disorders [5-9]. In fact, pro-inflammatory mediators, including tumor necrosis factor- $\alpha(\mathrm{TNF} \alpha)$, increment intracellular production of ROS, thus causing cellular damage. This also occurs in epithelial intestinal cells in response to the oxidative stress associated with chronic intestinal bowel disease (IBD), enteritis, and colon cancer [10]. Oxidative stress and inflammatory mediators alter intestinal barrier function and disrupt tight junctions by inducing changes in localization and expression of tight junctional proteins, such as occludins, cadherins, and claudins (Cls), among which are $\mathrm{Cl}-1$, Cl-2, and Cl-7 [11-13]. Moreover, in the intestine they are also involved in the increase of adhesion molecules, such as intercellular adhesion molecule-1 (ICAM-1), that contribute to the enhancement of trafficking leukocytes to inflammatory sites [14-16]. In particular, $\mathrm{TNF} \alpha$, the cytokine with a key role in the regulation of inflammatory processes in IBD [17], induced ROS increase, as well as ICAM-1 and Cl-2 expression up-regulation, in human epithelial colorectal adenocarcinoma cell line, HT29 cells [18,19]. Vitamin E protects the intestinal barrier against oxidative stress damage $[20,21]$, and it has an important role in the prevention of various pathologies, due to its antioxidant and anti-inflammatory action, and in down-regulating cell adhesion molecules, inhibiting platelet aggregation, and increasing nitric oxide synthase activity [22-24]. Indeed, vitamin E is able to promote positive biological responses independently of its antioxidant properties; being involved in the redox-independent regulation of gene expression, inhibition of protein kinase $C$ expression and activity, as well as cell proliferation [1]. Overall, to vitamin E has been attributed anti-cancer properties [25], and the ability to stimulate cellular immune response [26] and reduce the progression of Alzheimer's disease in patients with moderate pathology [27]. In fact, in conditions of vitamin E deficiency, anemia, neuromuscular and cardiovascular problems, and defective immune response can occur, causing heart disease, myopathies, and nerve damages [2]. Vitamin E deficiency is often present in IBD patients, and this can be due to bowel ulcerations and/or resection, which decrease the intestinal absorptive surface [28]. Administration of vitamin E reduces the development of experimental colitis in animal models [29,30], and semi-synthetic derivatives of vitamin E can also act as anti-inflammatory agents, inhibitors of nuclear factor-kappa B (NF-kB) translocation, and adjuvants in chemotherapeutic treatments [31-33].

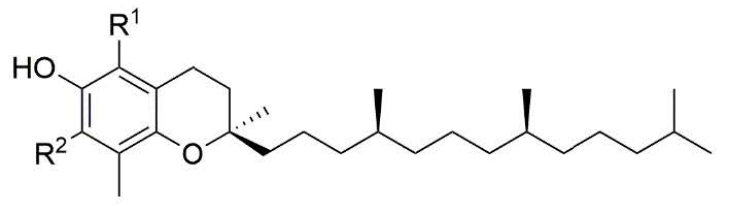

$$
\begin{aligned}
& \mathrm{R}^{1}=\mathrm{R}^{2}=\mathrm{H}: \delta \text {-Tocopherol }(\delta \text {-Toc) } \\
& \mathrm{R}^{1}=\mathrm{H}, \mathrm{R}^{2}=\mathrm{CH}_{3}: \gamma \text {-Tocopherol }(\gamma \text {-Toc) } \\
& \mathrm{R}^{1}=\mathrm{CH}_{3}, \mathrm{R}^{2}=\mathrm{H}: \beta \text {-Tocopherol }(\beta \text {-Toc) } \\
& \mathrm{R}^{1}=\mathrm{R}^{2}=\mathrm{CH}_{3}: \alpha \text {-Tocopherol }(\alpha-\mathrm{Toc})
\end{aligned}
$$

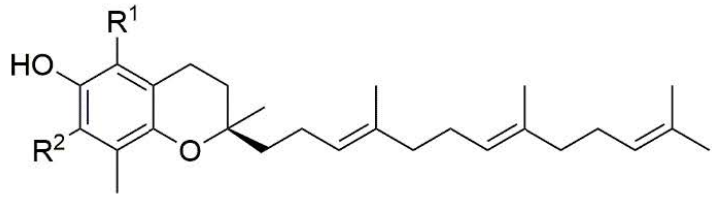

$$
\begin{aligned}
& \mathrm{R}^{1}=\mathrm{R}^{2}=\mathrm{H}: \delta \text {-Tocotrienol } \\
& \mathrm{R}^{1}=\mathrm{H}, \mathrm{R}^{2}=\mathrm{CH}_{3}: \gamma \text {-Tocotrienol } \\
& \mathrm{R}^{1}=\mathrm{CH}_{3}, \mathrm{R}^{2}=\mathrm{H}: \beta \text {-Tocotrienol } \\
& \mathrm{R}^{1}=\mathrm{R}^{2}=\mathrm{CH}_{3}: \alpha \text {-Tocotrienol }
\end{aligned}
$$

Figure 1. Structure of $\alpha_{-}^{-}, \beta-, \gamma_{-}$, and $\delta$-tocopherol $\left(\alpha-, \beta-, \gamma-\right.$, and $\delta$-Toc), and the corresponding $\alpha_{-}, \beta-, \gamma_{-}$, and $\delta_{-}$-tocotrienol.

The aim of this study was to investigate the protective role of natural, $\alpha$-Toc and $\delta$-Toc, and semi-synthetic, bis- $\delta$-tocopheryl sulfide and bis- $\delta$-tocopheryl disulfide, indicated as $\left(\delta\right.$-Toc) ${ }_{2} \mathbf{S}$ and $\left(\delta-\mathbf{T o c}_{2} \mathbf{S}_{2}\right.$, respectively [34], (Figure 2), on TNF $\alpha$-induced oxidative stress, and ICAM-1 and Cl-2 expression, in HT29 cells. 

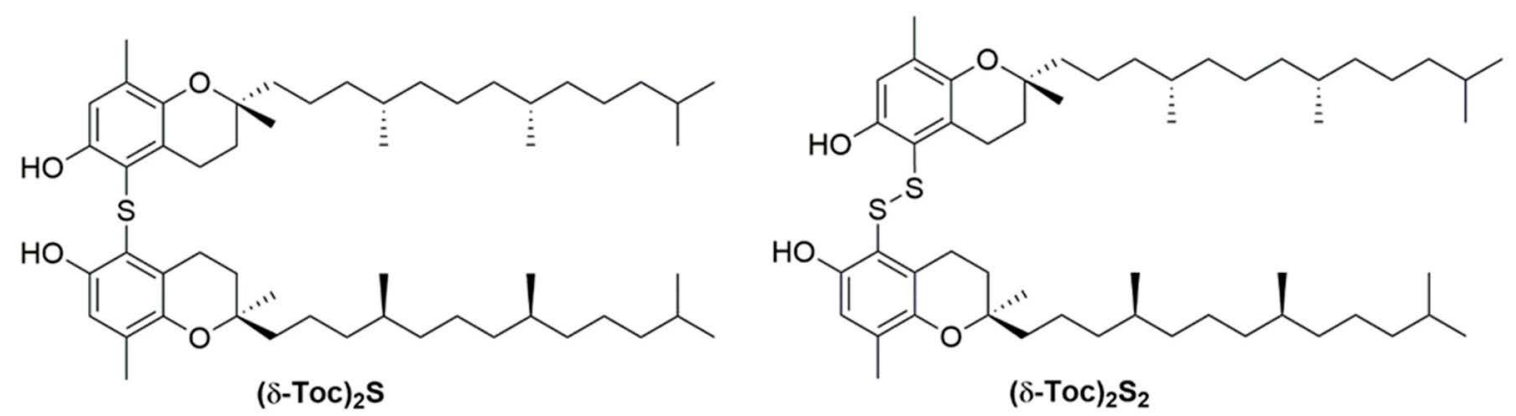

Figure 2. Structure of bis- $\delta$-tocopheryl sulfide $\left(\delta-\mathrm{Toc}_{2} \mathbf{S}\right.$ and bis- $\delta$-tocopheryl disulfide $\left(\delta-\mathrm{Toc}_{2} \mathbf{S}_{\mathbf{2}}\right.$ tested in this study.

Additionally, the relationship between the intracellular redox state and the expression of ICAM-1 and Cl-2 was evaluated in the same cells. To clarify the actual role of the antioxidant activity of the derivatives tested, the same experiments were performed in the presence of $\mathrm{N}$-acetylcysteine (NAC), an antioxidant precursor of glutathione, known to be able to reduce intracellular oxidative stress [35].

\section{Materials and Methods}

\subsection{Cell Culture and Treatment}

HT29 cells, obtained from the American Type Culture Collection (Manassas, VA, USA), were grown at $37{ }^{\circ} \mathrm{C}$ in a $5 \% \mathrm{CO}_{2}$ atmosphere in McCoy's 5A modified medium supplemented with $10 \%$ fetal bovine serum, $72 \mathrm{mg} / \mathrm{L}$ penicillin and $100 \mathrm{mg} / \mathrm{mL}$ streptomycin. Experiments were performed in cells seeded in 12-well plates, and at $80-90 \%$ confluence pre-treated or not for $1 \mathrm{~h}$ with various concentrations $(5-100 \mu \mathrm{N})$ of natural, $\alpha$-Toc and

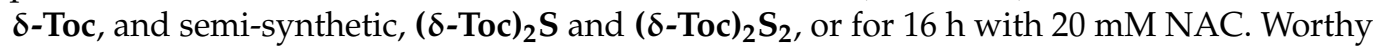
of mention is the use of normal concentration $(\mu \mathrm{N})$ for the tocopherol derivatives. Since $(\delta-\mathrm{Toc})_{2} S$ and $(\delta-\mathrm{Toc})_{2} S_{2}$ contain two $\delta$-tocopherol units, we decided to compare the effect of $\alpha$-Toc and $\delta$-Toc with the same concentration of tocopherol units in the sulfide and disulfide under investigation. In other words, the molar concentration of $(\delta-\mathrm{Toc})_{2} \mathrm{~S}$ and $(\delta-\text { Toc })_{2} S_{2}$ used in these experiments was $\frac{1}{2}$ of that of $\alpha$-Toc and $\delta$-Toc. Subsequently, these cells were stimulated or not for another $24 \mathrm{~h}$ with $10 \mathrm{ng} / \mathrm{mL} \mathrm{TNF} \alpha$. The vitamin $\mathrm{E}$ isoform concentration range included those reported in the literature [36,37]. We utilized concentrations as low as 5 and $10 \mu \mathrm{N}$, and as high as 50 and $100 \mu \mathrm{N}$. Then, $0.7 N$ solutions of $\alpha$-Toc, $\delta$-Toc, $(\delta \text {-Toc })_{2} S$, and ( $\delta$-Toc) ${ }_{2} S_{2}$ in ethanol were diluted with phosphate bufferedsaline (PBS) in order to reach the required concentration of antioxidant to be added to the cells. A final homogenous solution was achieved in all cases, and $0.008 \%$ ethanol was added to the respective vitamin E-untreated cells. All reagents used for cell culture and stimulation were purchased from Sigma-Aldrich (St. Louis, MO, USA).

\subsection{Cell Viability by Trypan Blue Dye Exclusion Test}

Cell viability was measured in HT29, treated or not with the highest concentrations (50 and $100 \mu \mathrm{N}$ ) of natural, $\alpha$-Toc and $\delta$-Toc, and semi-synthetic, $\left(\delta\right.$-Toc) ${ }_{2} \mathbf{S}$ and ( $\delta$-Toc) ${ }_{2} \mathbf{S}_{2}$, or $20 \mathrm{mM} \mathrm{NAC}$, as above described, and stimulated for $24 \mathrm{~h}$ with $10 \mathrm{ng} / \mathrm{mL} \mathrm{TNF} \alpha$. Cells, detached with trypsin and collected by centrifugation at $130 \times g$ for $10 \mathrm{~min}$, were resuspended in cold phosphate buffer saline (PBS). Next, $40 \mu \mathrm{L}$ cell suspension was mixed with equal parts of $0.4 \%$ trypan blue dye, loaded into a Neubauer chamber, and viewed under a microscope. The number of dead (stained) and live cells (unstained) was manually counted. The percentage of viable cells was calculated considering the ratio between number of unstained cells and number of total cells ratio $\times 100$.

\subsection{Bis- $\delta$-Tocopheryl Sulfide $(\delta \text {-Toc })_{2} S$ and Bis- $\delta$-Tocopheryl Disulfide $(\delta \text {-Toc })_{2} S_{2}$ Synthesis}

Bis- $\delta$-tocopheryl sulfide ( $\delta$-Toc) ${ }_{2} \mathbf{S}$ and bis- $\delta$-tocopheryl disulfide $\left(\delta\right.$-Toc) ${ }_{2} \mathbf{S}_{2}$ were prepared by regioselective sulfenylation of $\delta$-Toc with the phthalimidesulfenyl chloride $\mathrm{Ph}$ tNSCl (Pht = Phthaloyl). The ortho-hydroxy-N-thiophthalimide derivative obtained was 
used as common starting material for the synthesis of both compounds. Bis- $\delta$-tocopheryl sulfide $\left(\delta-\mathbf{T o c}_{2} \mathbf{S}\right.$ was the product of the reaction of ortho-hydroxy- $\mathrm{N}$-thiophthalimide and $\delta$-Toc in the presence of triethylamine [34], and Bis- $\delta$-tocopheryl disulfide ( $\delta$-Toc) $\mathbf{2}_{2} \mathbf{S}_{2}$ was the result of the reaction of the ortho-hydroxy- $N$-thiophthalimide with bis-trimetylsilyl selenide $\left(\mathrm{Me}_{3} \mathrm{Si}\right)_{2} \mathrm{Se}$ [38]. Both compounds were carefully purified by silica gel flesh column chromatography, and fully characterized [34].

\subsection{Intracellular ROS Production Assay}

The intracellular production of ROS was detected, as previously described [39], by using $2^{\prime}-7^{\prime}$-dichlorodihydrofluorescein diacetate (H2DCF-DA) (Invitrogen, Carlsbad, CA, USA), a fluorogenic dye, which within the cells is deacetylated by esterase to a non-fluorescent compound, subsequently oxidized by ROS into the fluorescent $2^{\prime}-7^{\prime}$ dichlorodihydrofluorescein (DCF). A total of $5 \mathrm{mg} / \mathrm{L}$ (H2DCF-DA) was added to HT29 cells, treated as described above, $30 \mathrm{~min}$ before the end of TNF $\alpha$ stimulation. HT29 cells were washed and lysed in a buffer containing $50 \mathrm{mM}$ Tris/ $\mathrm{HCl} \mathrm{pH} \mathrm{7.5,} \mathrm{1 \%} \mathrm{Triton} \mathrm{X-100,}$ $150 \mathrm{mM} \mathrm{NaCl}, 100 \mathrm{mM} \mathrm{NaF}$, and 2 mM EGTA. Fluorescence intensity was measured using a Fluoroskan AscentFL microplate reader (Thermo Fisher Scientific, Waltham, MA, USA) at $485 \mathrm{~nm}$ excitation and $518 \mathrm{~nm}$ emission wavelengths. Data, normalized on total protein content, were expressed as the percentage of ROS detected in untreated and unstimulated cells (control).

\subsection{ICAM-1 and Cl-2 Assay}

ICAM-1 and Cl-2 expression was detected by measuring intracellular ICAM-1 and Cl-2 levels in the cell lysates of HT29 cells, treated as described above, using a Human ICAM-1 ELISA kit (Uscn Life Sciences Inc., Wuhan, Hubei, PRC) and Human Claudin-2 ELISA kit (MyBiosource, San Diego, CA, USA), in accordance with the manufacturer's instructions. Cell lysates were obtained by HT29 detached with trypsin, and collected by centrifugation at $130 \times g$ for $10 \mathrm{~min}$. Cells, washed three times and resuspended in cold PBS, were ultrasonicated four times for $15 \mathrm{~s}$. Subsequently, the cell lysates were centrifuged at $1500 \times g$ for $10 \mathrm{~min}$ to remove cellular debris, and the supernatants were used to perform ICAM-1 and Cl-2 assays. Data, normalized on total protein content, were expressed as percent of ICAM-1 or Cl-2 levels detected in controls.

\subsection{Protein Assay}

Protein concentration was detected by the bicinchoninic acid solution (BCA) protein reagent assay (Thermo Scientific, Waltham, MA, USA), using bovine serum albumin (SigmaAldrich) as a standard [40].

\subsection{Statistical Analysis}

GraphPad Prism software was used to determine the statistical significance of the differences by one-way ANOVA analysis with Bonferroni's multiple comparison test. All experiments were carried out three times, and data are expressed as the mean \pm SEM. $p \leq 0.05$ was considered statistically significant.

\section{Results}

3.1. Effect of Natural $\alpha$-Toc and $\delta$-Toc, Semi-Synthetic, $(\delta-T o c)_{2} S$ and $(\delta-T o c)_{2} S_{2}$, and NAC on HT29 Cell Viability

Figure 3 shows that cell viability did not undergo significant changes in HT29 stimulated with $\mathrm{TNF} \alpha$, both in the absence and in the presence of NAC, or the highest concentrations used (50 and $100 \mu \mathrm{N}$ ) of natural, $\alpha$-Toc and $\delta$-Toc, and semi-synthetic, $(\delta \text {-Toc })_{2} S$ and $(\delta-\mathrm{Toc})_{2} S_{2}$. This indicates that, in our experimental conditions, cell viability was not altered, and the various tocopherol derivatives were not cytotoxic. In this light, in further experiments, all tocopherols were used at these or lower concentrations. 


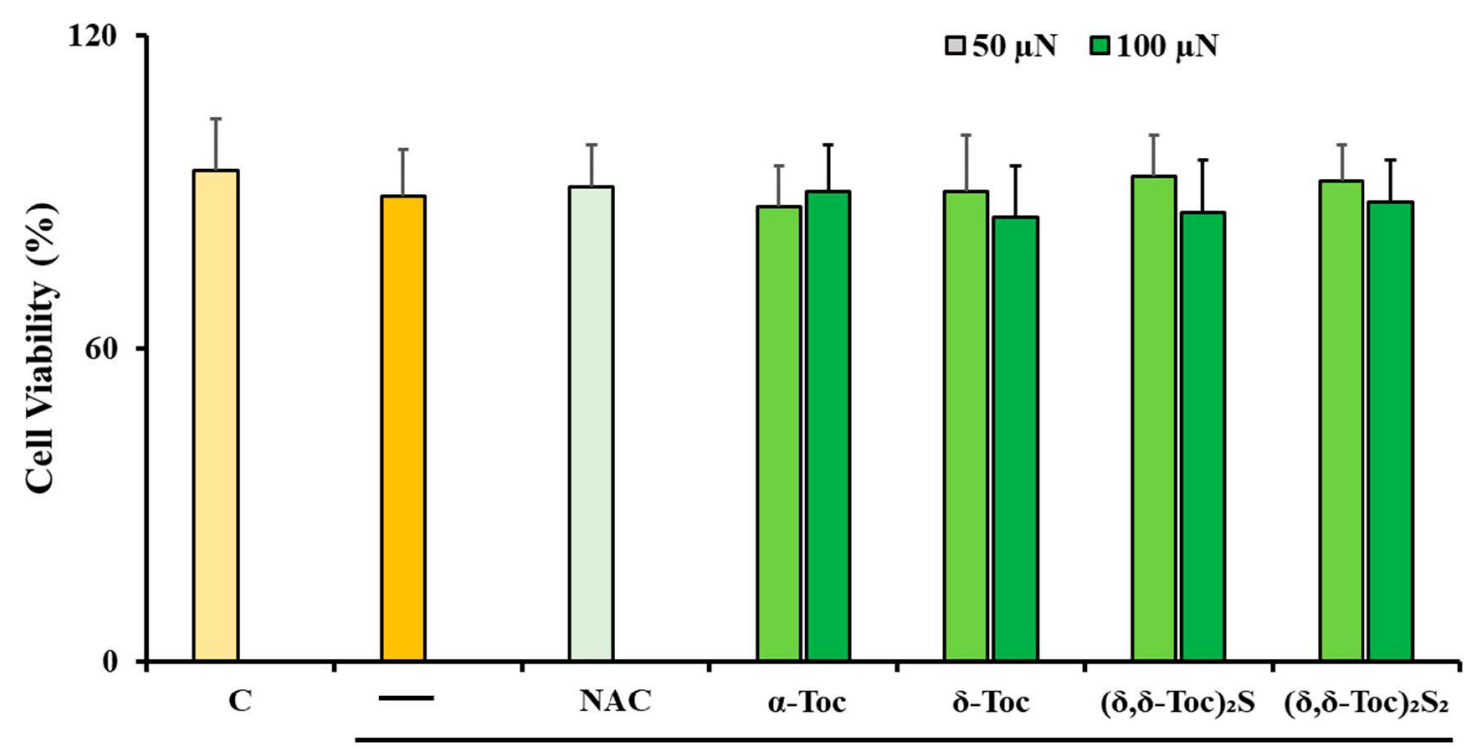

TNFa

Figure 3. Viability of HT29 pre-treated with natural, $\alpha$-Toc and $\delta$-Toc, semi-synthetic, $(\delta \text {-Toc })_{2} S$ and $(\delta \text {-Toc })_{2} S_{2}$, or NAC, and stimulated with TNF $\alpha$. HT29 cells, pre-treated or not with 50 and $100 \mu \mathrm{N}$ of $\alpha$-Toc, $\delta$-Toc, $(\delta \text {-Toc) })_{2} \mathbf{S},(\delta-T o c)_{2} \mathbf{S}_{2}$, or $20 \mathrm{mM}$ NAC, as reported in Materials and Methods, were stimulated or not for $24 \mathrm{~h}$ with $10 \mathrm{ng} / \mathrm{mL}$ TNF $\alpha$. Cell viability was performed by Trypan blue dye exclusion test. Percentage of viable cells was calculated considering the ratio between the number of unstained cells and the number of total cells $\times 100$. Values are the mean \pm SEM of three experiments repeated in triplicate.

3.2. Effect of Natural $\alpha$-Toc and $\delta$-Toc, Semi-Synthetic, $(\delta \text {-Toc })_{2} S$ and $(\delta \text {-Toc })_{2} S_{2}$, and NAC on TNF $\alpha$-Induced ROS Production in HT29 Cells

Oxidative stress was detected by measuring intracellular ROS production in TNF $\alpha$ stimulated HT29 cells pre-treated or not with various concentrations $(5-100 \mu \mathrm{N})$ of $\alpha$ -

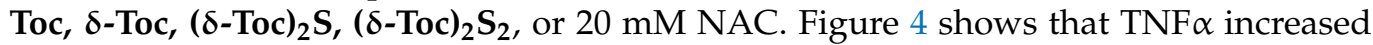
significantly intracellular ROS levels, by about $120 \%$, as compared to control cells, and that this ROS increase did not occur in NAC pre-treated HT29 cells. Tocopherols pre-treatment did not prevent TNF $\alpha$-induced ROS production in a concentration-dependent manner. In fact, pre-treatment with low concentrations of $\alpha$-Toc and $\delta$-Toc $(5$ and $10 \mu \mathrm{N})$ did not prevent a TNF $\alpha$-induced ROS increase in TNF $\alpha$-stimulated HT29 cells. Conversely, when $\alpha$-Toc and $\delta$-Toc were used at high concentrations $(50$ and $100 \mu \mathrm{N})$ they totally prevented ROS production (Figure 4). ( $\delta$-Toc $)_{2} \mathbf{S}$ and $(\delta-\mathrm{Toc})_{2} \mathbf{S}_{2}$ were able to inhibit the increase of ROS levels in TNF $\alpha$-stimulated cells, both at low and high concentrations $(5-100 \mu N)$

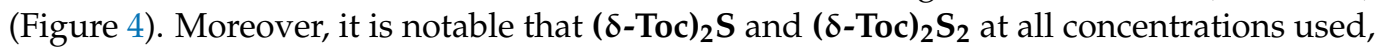
as well as $\alpha$-Toc and $\delta$-Toc at 50 and $100 \mu \mathrm{N}$, prevented TNF $\alpha$-induced ROS production similarly to NAC. To better clarify the trend of the dose-response curve, we detected ROS values in HT29 pre-treated with a lower and a higher concentration of tocopherols. Figure 4 shows that the pre-treatment of HT29 cells with $1 \mu \mathrm{N}$ or $300 \mu \mathrm{N} \alpha$-Toc and $\delta$-Toc did not prevent TNF $\alpha$-induced ROS increase. While data obtained with $1 \mu \mathrm{N}$ concentration are perfectly in line with previously discussed data, the increase of ROS using $300 \mu \mathrm{N}$ concentration of natural $\alpha$-Toc and $\delta$-Toc seems in accordance with the already reported and intriguing pro-oxidant role of vitamin E observed in several experiments, particularly when used at high concentrations [41-44]. 
A

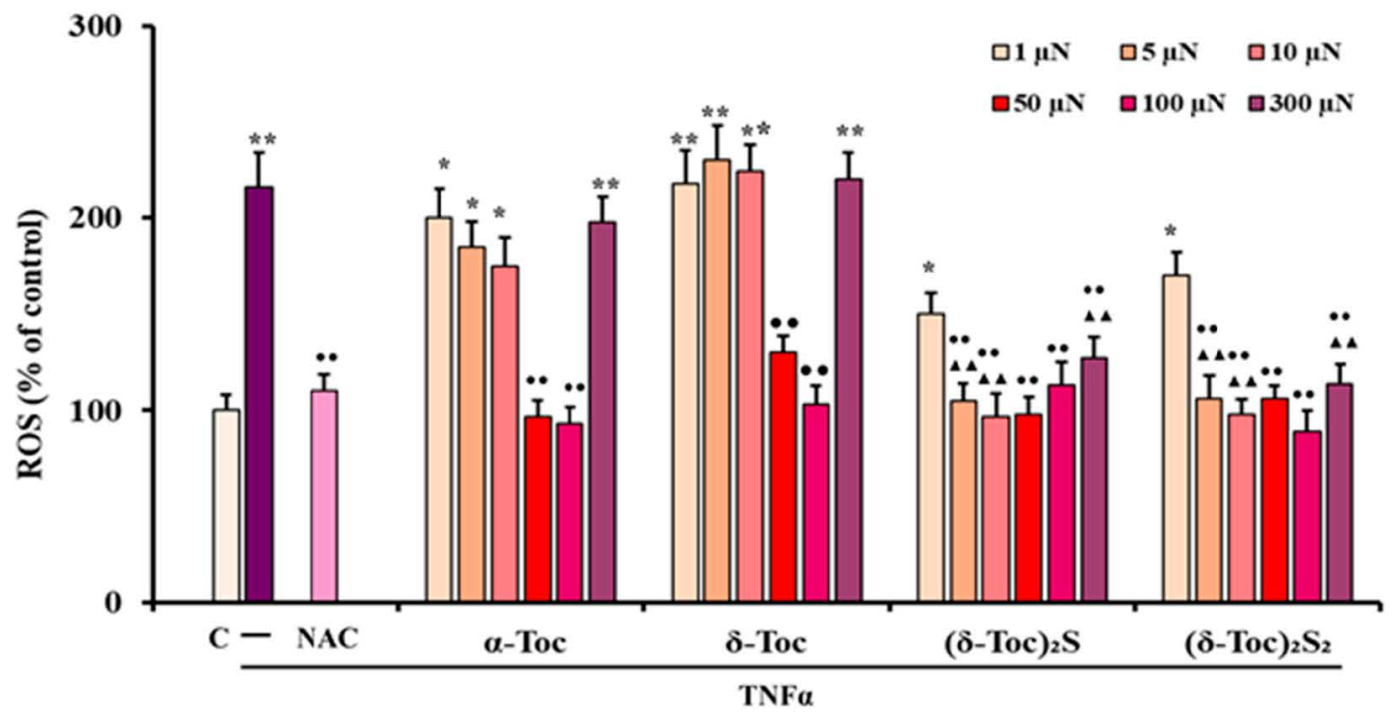

B

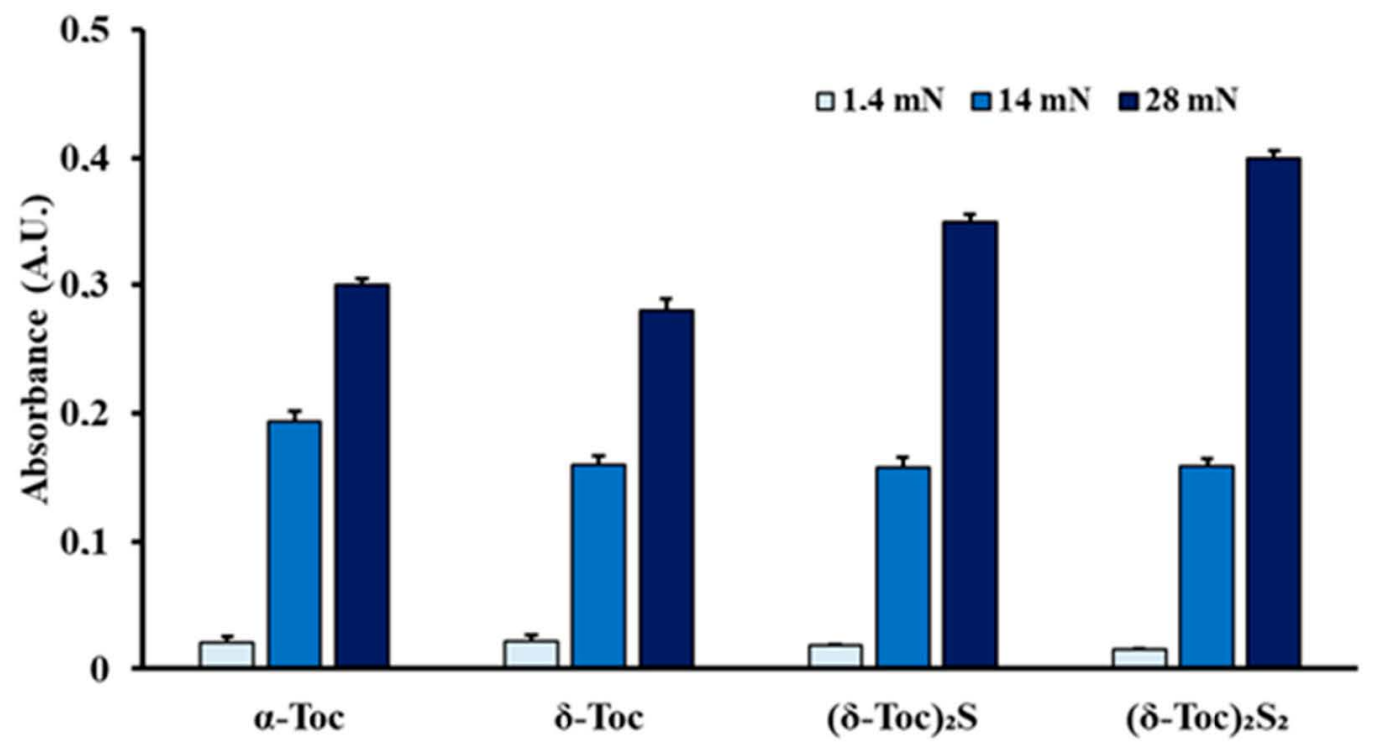

Figure 4. Intracellular ROS production in HT29 cells pre-treated or not with natural, $\alpha$-Toc, $\delta$-Toc, semi-synthetic, $\left(\delta\right.$-Toc) ${ }_{2} \mathbf{S}$, $(\delta-T o c){ }_{2} S_{2}$, or NAC, and stimulated with TNF $\alpha(A)$ and solubility of tocopherols (B). HT29, pre-treated or not with various concentrations $(1-300 \mu \mathrm{N})$ of $\alpha$-Toc, $\delta$-Toc, $(\delta \text {-Toc })_{2} \mathbf{S},(\delta \text {-Toc })_{2} \mathbf{S}_{2}$, or $20 \mathrm{mM} \mathrm{NAC}$, as reported in Materials and Methods, were stimulated or not for $24 \mathrm{~h}$ with $10 \mathrm{ng} / \mathrm{mL} \mathrm{TNF} \alpha$. The intracellular ROS production was assayed by measuring the fluorescence intensity of the intracellular oxidation-sensitive probe H2DCFDA. The values, normalized on total protein content and expressed as the percentage of untreated and unstimulated cells (control, C), are the mean \pm SEM of three experiments repeated in triplicate. Solubility of natural and semi-synthetic tocopherols was detected at concentrations (1.4-28 mN) obtained by diluting in PBS 0.7 N solutions in ethanol. Relative absorbance was measured at $292 \mathrm{~nm}$. Data are the mean \pm SEM of three experiments, and are expressed as arbitrary unit (A.U). ${ }^{*} p \leq 0.05$; ${ }^{* *} p \leq 0.001$ compared to C cells; $\bullet p \leq 0.001$ compared to untreated and TNF $\alpha$-stimulated cells; ${ }^{\boldsymbol{\Delta}} \boldsymbol{\Delta} p \leq 0.001$ compared to $\alpha$-Toc and $\delta$-Toc pre-treated, and $\mathrm{TNF} \alpha$-stimulated cells. 
On the other hand, semisynthetic $\left(\delta-\mathbf{T o c}_{2} \mathbf{S}\right.$ and $(\delta-\mathbf{T o c})_{2} \mathbf{S}_{2}$ showed a limited decrease of ROS values in TNF $\alpha$-stimulated HT29 cells, even when used at $1 \mu \mathrm{N}$ concentration. Moreover, when they were used at $300 \mu \mathrm{N}$ the ROS values were similar to those measured in the range 5-100 $\mu \mathrm{N}$, and with a limited increase if compared with those observed for $\alpha$-Toc and $\delta$-Toc. These data, confirming the beneficial effect exerted by our semi-synthetic derivatives in a huge range of concentrations, support the lack of a direct dose-effect relationship, either for $(\delta-\mathrm{Toc})_{2} S,\left(\delta-\mathrm{Toc}_{2} \mathrm{~S}_{2}\right.$ in all concentration ranges tested, or for $\alpha$-Toc and $\delta$-Toc in the 5-100 $\mu \mathrm{N}$ concentration range. As described in Section 2.1, to reach the concentrations used of semi-synthetic and natural tocopherols in the cells, their $0.7 \mathrm{~N}$ solutions in ethanol were subsequently diluted in PBS. To definitively demonstrate that the lack of a direct dose-effect was not due to solubility issues of our lipophilic derivatives under the measured conditions, we prepared, as described, 1.4, 14, and $28 \mathrm{mN}$ solutions of the compounds tested, i.e., from 14 to 280 times more concentrated than the upper limit $(100 \mu \mathrm{N})$ concentration typically tested. The increase of the concentration was verified as proportional absorbance detected by UV-Vis spectra at $292 \mathrm{~nm}$, as already reported [45] in Figure 4B. Hence, all tocopherols used were perfectly soluble in our experimental conditions, and the lack of a direct dose-effect relationship was not caused by the low solubility of tocopherols but, reasonably, was due to the complexity of the biological system, and mechanisms involved in the formation of ROS in the system under investigation.

3.3. Effect of Natural $\alpha$-Toc and $\delta$-Toc, Semi-Synthetic, $(\delta \text {-Toc })_{2} S$ and $(\delta-T o c)_{2} S_{2}$, and NAC on TNF $\alpha$-Induced ICAM-1 and Cl-2 Expression in HT29 Cells

ICAM-1 and Cl-2 expression was detected in TNF $\alpha$-stimulated HT29 cells pre-treated or not with intermediate concentrations of all tocopherol derivatives (10 and $50 \mu \mathrm{N})$ or $20 \mathrm{mM}$ NAC. Figure 5A shows that TNF $\alpha$ up-regulated ICAM- 1 expression by about $250 \%$, compared to control cells. In addition, $10 \mu \mathrm{N} \alpha$-Toc, $\delta$-Toc were not able to prevent this,

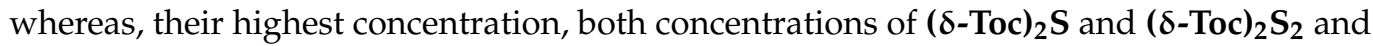
NAC, totally prevented the increase of ICAM-1 due to TNF $\alpha$ stimulation. This effect is in accordance with what was observed in the ROS production experiment, indicating a clear relationship between ICAM-1 expression and the intracellular redox state. TNF $\alpha$ also induced a significant increase, of about 95\%, in Cl-2 expression, which was reduced, partially but significantly, by pre-treatment with $10 \mu \mathrm{N} \alpha$-Toc and $\delta$-Toc and NAC, compared to TNF $\alpha$-stimulated cells, (Figure 4B). However, in these experimental conditions, Cl-2 levels were significantly higher than those detected in control cells, and not closely related to ROS levels, differently to those observed in ICAM-1 expression. The pre-treatment with $50 \mu \mathrm{N}$ $\alpha$-Toc and $\delta$-Toc, and the bis- $\delta$-tocopheryl sulfide and disulfide, $(\delta-T o c)_{2} S,(\delta \text {-Toc })_{2} S_{2}$, at both concentrations, was able to completely prevent the up-regulation of TNF $\alpha$-induced Cl-2 expression. 


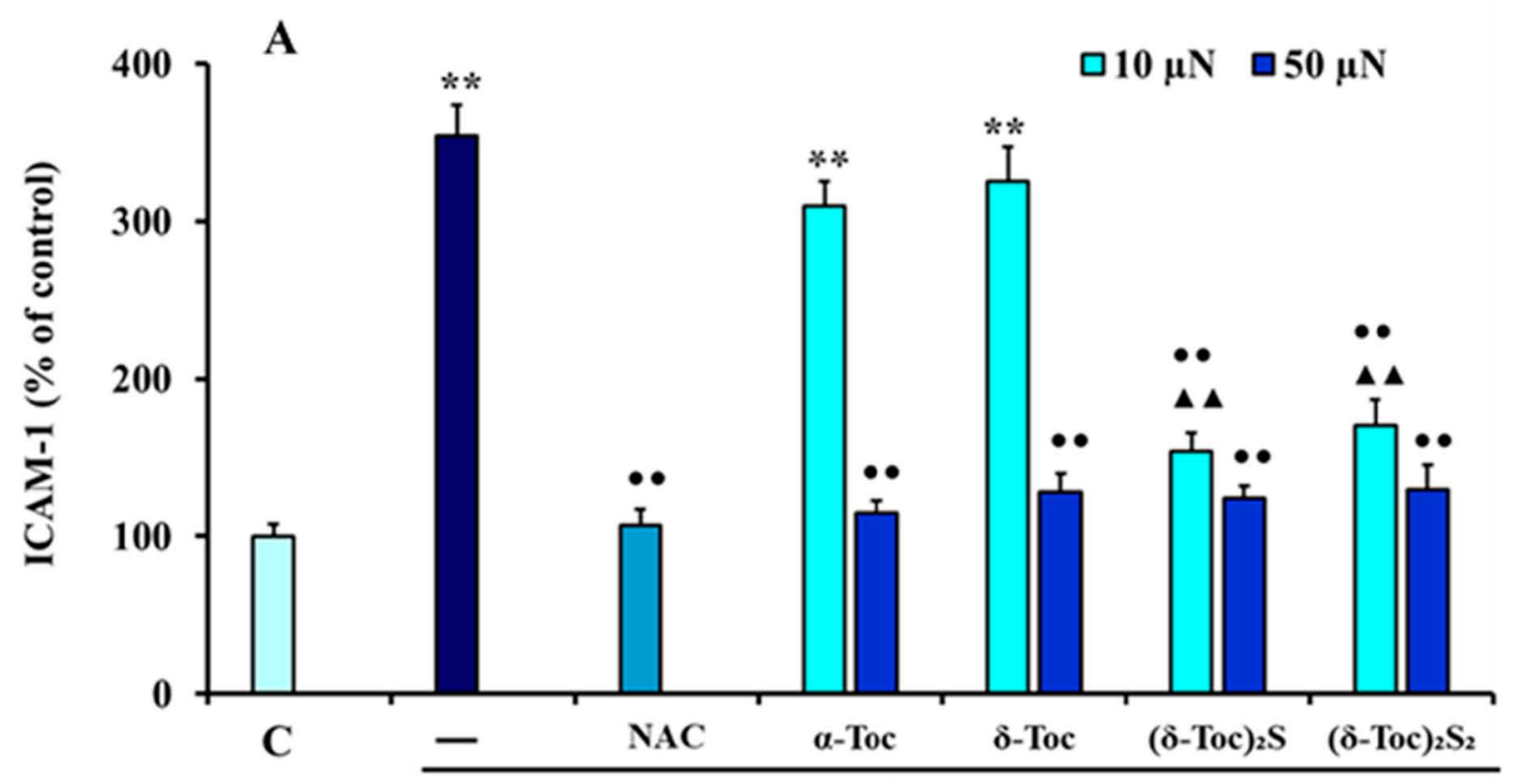

TNFo

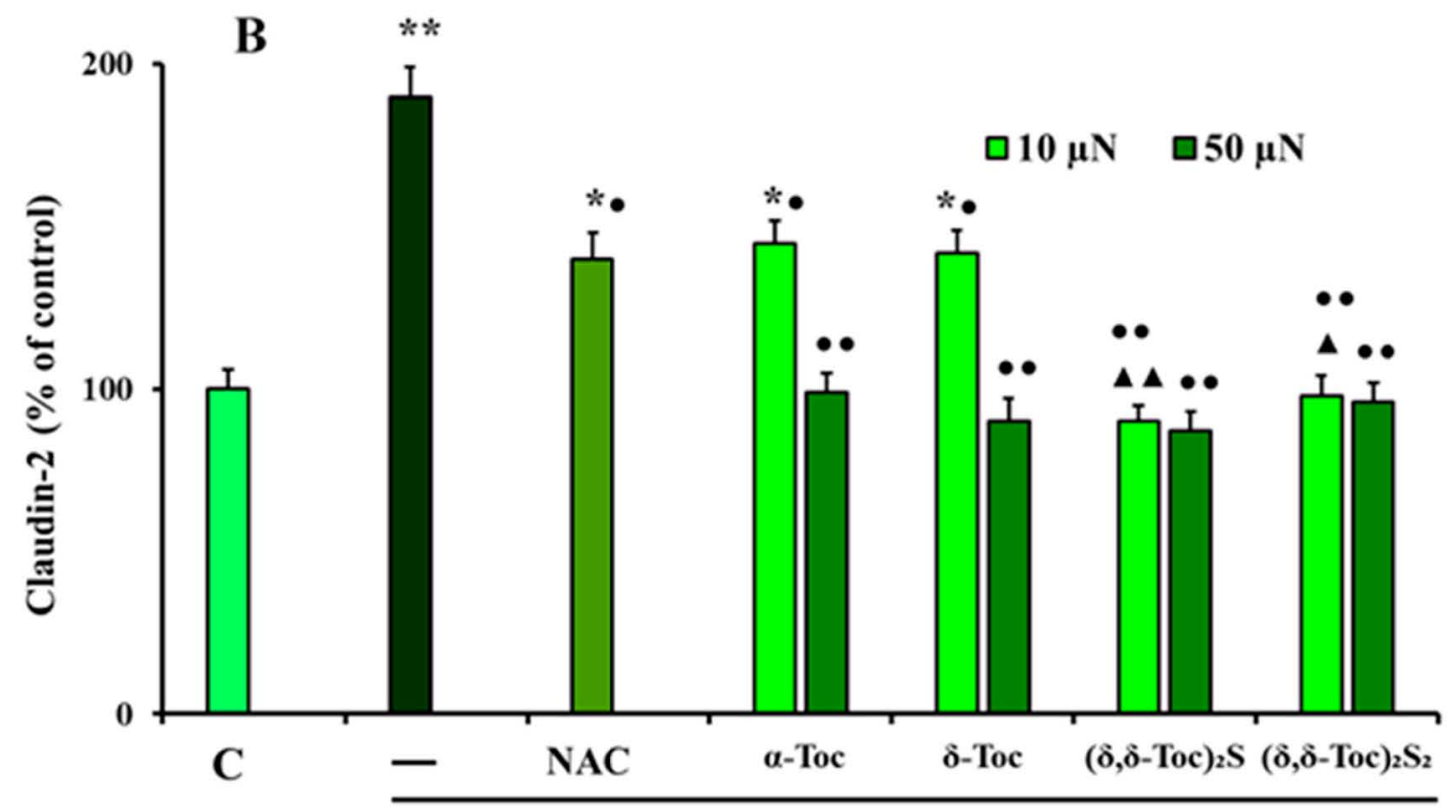

TNFa

Figure 5. ICAM-1 and Cl-2 expression in HT29 cells pre-treated or not with natural, $\alpha$-Toc, $\delta$-Toc, semi-synthetic, $\left(\delta\right.$-Toc) ${ }_{2} \mathbf{S}$, $(\delta-\mathrm{Toc})_{2} \mathrm{~S}_{2}$, or NAC, and stimulated with TNF $\alpha$. HT29, pre-treated or not with various concentrations $(10-50 \mu N)$ of $\alpha$-Toc, $\delta$-Toc, $(\delta-T o c){ }_{2} S,(\delta-T o c){ }_{2} S_{2}$, or $20 \mathrm{mM} \mathrm{NAC}$, as reported in Materials and Methods, were stimulated or not for $24 \mathrm{~h}$ with $10 \mathrm{ng} / \mathrm{mL}$ TNF $\alpha$. ICAM-1 levels (A) and Cl-2 levels (B) were assayed by ELISA kits in cell lysates. The values, expressed as the percentage of untreated and unstimulated cells (control, $\mathrm{C}$ ), are the mean \pm SEM of three experiments repeated in triplicate. ${ }^{*} p \leq 0.05,{ }^{* *} p \leq 0.001$ compared to C cells; ${ }^{\bullet} p \leq 0.05,{ }^{\bullet \bullet} p \leq 0.001$ compared to untreated and TNF $\alpha$-stimulated cells; ${ }^{\boldsymbol{\Delta}} p \leq 0.05, \boldsymbol{\Delta} p \leq 0.001$ compared to $\alpha$-Toc and $\delta$-Toc pre-treated, and TNF $\alpha$-stimulated cells. 


\section{Discussion}

For the first time, it has been demonstrated that the pre-treatment of TNF $\alpha$-stimulated cells with natural, $\alpha$-Toc and $\delta$-Toc, and semi-synthetic, $(\delta-T o c)_{2} \mathbf{S}$ and $(\delta-T o c)_{2} S_{2}$, prevents the increase of ROS, Cl-2, and ICAM-1 levels.

This result deserves to be commented on as being deceptively obvious. The antioxidant activity of tocopherol is well known, and $\alpha$-Toc is typically indicated, at least in vitro, as the more potent natural lipophilic natural antioxidant [46,47]. This is completely true when considering the chain breaking antioxidant activity, and the ability of tocopherols to react with peroxyl radicals $\left(\mathrm{ROO}^{*}\right)$. In this reaction the kinetic inhibition constant of $\alpha$-Toc is $k_{\text {inh }}=3.2 \times 10^{6} \mathrm{~mol}^{-1} \mathrm{~s}^{-1}$, the highest value measured for natural phenolic antioxidants. However, $\delta$-Toc, due to the lack of two methyl groups on the aromatic ring, is roughly one order of magnitude less active than $\alpha$-Toc as a chain breaking antioxidant with a $k_{\text {inh }}=4.4$ $\times 10^{5} \mathrm{~mol}^{-1} \mathrm{~s}^{-1}$ difference that is not observed in the measures reported in this manuscript. In the last two decades we have studied the effect of sulfur introduction on the activity of natural phenolic antioxidants [48-60]. In particular, the synthesis of $(\delta-T o c)_{2} S$ and $(\delta-$ Toc) ${ }_{2} \mathbf{S}_{2}$, and related tocopherol sulfides and disulfides [34], has allowed us to measure their chain breaking antioxidant activity. Thus, we demonstrated that sulfides show an activity slightly worse than the corresponding tocopherol, for example for $(\delta-T o c){ }_{2} \mathbf{S} k_{i n h}=2.2 \times$ $10^{5} \mathrm{~mol}^{-1} \mathrm{~s}^{-1}$, but that a single tocopherol unit is operative as a peroxyl radical (ROO*) quencher. On the other hand, tocopheryl disulfides were a further order of magnitude less active than the corresponding tocopherols, $\left(\delta-\mathbf{S o c}_{2} \mathbf{S}_{2} k_{i n h}=1.5 \times 10^{4} \mathrm{~mol}^{-1} \mathrm{~s}^{-1}\right.$ [34]. Thus, it appears that the clear antioxidant effects observed and reported in this manuscript were not related to the ability of tocopherols for quenching $\mathrm{ROO}^{*}$ radicals or other related oxygen centered radicals. This was confirmed by the results achieved with bis- $\delta$-tocopheryl sulfide and disulfide, $\left(\delta-\mathrm{Toc}_{2} \mathrm{~S},(\delta-\mathrm{Toc})_{2} \mathrm{~S}_{2}\right.$, which, very interestingly, exerted their activity with both the tocopheryl units.

The present study also shows that TNF $\alpha$-induced oxidative stress can be involved in the up-regulation of $\mathrm{Cl}-2$ and ICAM-1 expression in intestinal HT29 cells. These are cancer cells with characteristics of mature intestinal cells, and for this they represent a useful in vitro model for studying the antioxidant or barrier protective properties of food compounds [61,62]. Literature data show that in HT29 cells TNF $\alpha$ induces ROS production and $\mathrm{Cl}-2$ and ICAM-1 expression up-regulation $[17,18]$. However, to our knowledge, there are no data regarding the role of natural and semi-synthetic vitamin $\mathrm{E}$ isoforms in the prevention of TNF $\alpha$-induced oxidative stress and the expression of molecules involved in the adhesion processes and intestinal barrier function in these cells. Moreover, the literature lacks clear information on the relationship between oxidative stress and ICAM-1 and $\mathrm{Cl}-2$ expression up-regulation in TNF $\alpha$-stimulated HT29 cells. ICAM-1, a glycoprotein expressed on the surface of various cell types, is involved in leukocyte trans-migration to inflammatory sites, and it is up-regulated in the colonic epithelial cells of patients with IBD [63]. Instead, Cl-2, a member of the transmembrane tight-junctional proteins, forms cation selective channels, and is highly expressed in IBD, contributing to alteration of intestinal barrier function [20,64-66]. In TNF $\alpha$-stimulated HT29 cells the enhancement of ROS levels seems to be involved in the up-regulation of ICAM- 1 and $\mathrm{Cl}-2$ expression, considering that NAC pre-treatment is able to down-regulate the increase of ROS, ICAM-1, and $\mathrm{Cl}-2$ levels. Moreover, natural and semi-synthetic tocopheryl derivatives reduce TNF $\alpha$ induced ROS production, and Cl-2 and ICAM-1 expression. However, the expression of ICAM-1 is directly related to intracellular redox state. In fact, the low concentrations of $\alpha$ Toc and $\delta$-Toc were unable to prevent both ROS and ICAM-1 increase in TNF $\alpha$-stimulated cells; differently to what occurs when they are used at high concentrations. It should be noted that ( $\delta$-Toc) ${ }_{2} S$ and $(\delta-T o c)_{2} S_{2}$ are more efficient than $\alpha$-Toc and $\delta$-Toc in preventing both ROS production and ICAM-1 expression increase. In fact, bis- $\delta$-tocopheryl sulfide and disulfide, contrarily to $\alpha$-Toc and $\delta$-Toc, at both low and high concentrations, are able to completely prevent the increase of ROS levels and ICAM-1 expression increase, similarly to large excesses of NAC. These data indicate that in HT29 cells TNF $\alpha$ up-regulates the 
expression of ICAM-1 only by redox regulated mechanisms, differently to those verified in intestinal myofibroblasts, in which TNF $\alpha$ up-regulates ICAM-1 expression by both redox-dependent and-independent mechanisms $[67,68]$. On the other hand, both these mechanisms appear to be involved in the TNF $\alpha$-induced up-regulation of $\mathrm{Cl}-2$ expression that in HT29 cells is not directly related to ROS levels. In fact, pre-treatment with NAC or $10 \mu \mathrm{N} \alpha$-Toc or $\delta$-Toc partially prevents $\mathrm{Cl}$ - 2 expression increase in TNF $\alpha$-stimulated cells, although only NAC was able to suppress ROS increase. We can speculate that, in our experimental conditions, NAC mainly inhibits the redox-regulate mechanisms, by preventing ROS production, whereas $10 \mu \mathrm{N} \alpha$-Toc or $\delta$-Toc suppress the non-redox-regulate mechanisms by processes not directly related to the antioxidant action. Instead, $\alpha$-Toc and $\delta$-Toc, at the highest concentration, and $(\delta-T o c)_{2} S$ and $(\delta-T o c)_{2} S_{2}$, at both concentrations, are able to avoid the increase of ROS in a similar manner to NAC but, differently from this, are also able to prevent the total up-regulation of $\mathrm{Cl}-2$ expression, probably through the inhibition of TNF $\alpha$-related redox- and non-redox-dependent mechanisms. $(\delta-T o c)_{2} S$ and $(\delta-T o c)_{2} S_{2}$ are much more effective than natural vitamin $E$ isoforms in the prevention of $\mathrm{Cl}-2$ up-regulation in TNF $\alpha$-stimulated HT29 cells, similarly to that which occurs for ROS production and ICAM-1 expression. Altogether, these results suggest that, in TNF $\alpha$-stimulated HT29 cells, natural tocopherols and semi-synthetic tocopheryl sulfide and disulfide prevent the increase of expression of ICAM- 1 and $\mathrm{Cl}-2$ thanks to their antioxidant properties. However, vitamin $\mathrm{E}$ can also suppress $\mathrm{Cl}-2$ expression by its ability to regulate redox-independent mechanisms. It is possible that the pre-treatment with the various tocopheryl derivatives in TNF $\alpha$-stimulated HT29 cells prevents the oxidative stress, and then the activation of redox-sensitive regulatory transcription factors, such as NF-kB. In fact, TNF $\alpha$ administration to an animal model can up-regulate ICAM- 1 and Cl-2 expression by NF-kB activation [69,70], as in various types of cells stimulated with $\mathrm{TNF} \alpha$ [71-73]. Vitamin E reduces the phenobarbital-induced NF-kB activation in rats [74], and $\delta$-Toc inhibits the phosphorylation of a kinase essential for TNF $\alpha$-induced NF-kB activation in macrophages [75]. Moreover, $\delta$-Toc prevents constitutive NF-kB activation in pancreatic cancer [76], and $\alpha$-Toc succinate reduces NF-kB activity and ICAM-1 expression in prostate cancer cells [77]. Vitamin E can also modulate biological responses and signaling pathways, by mechanisms independent of its antioxidant role [1,78]. Indeed, vitamin $\mathrm{E}$, by inhibiting protein kinase $\mathrm{C}$ (PKC) activity, down-regulates in cells many events, including inflammation, proliferation, adhesion, and migration [79]. In HT29/B6 cells, a sub-clone of the HT29 cell line, TNF $\alpha$ mediates the up-regulation of $\mathrm{Cl}-2$ expression by activating the phosphatidylinositol-3-kinase (PI3K) pathway and NF-kB [80,81]. We also speculate that, in our experimental conditions TNF $\alpha$ could up-regulate $\mathrm{Cl}-2$ expression by mechanisms that involved NF-kB and PI3K activation, and that tocopherols, by their non-antioxidant properties, could affect $\mathrm{Cl}-2$ expression by inhibiting PKC that may be activated downstream of PI3K [82,83]. Vitamin E down-regulates oxidative stress and adhesion molecule expression in the inflammatory processes present in various diseases [84-87], and reduces ICAM-1 in cultured microglial cells [88], as well as in human aortic endothelial cells [89]. Moreover, vitamin E ameliorates oxidative stress in the intestine of animals, and maintains the integrity and the correct functionality of the intestinal barrier $[90,91]$. The administration of certain vitamin E derivatives to animals with experimental colitis decreases colonic injury, intestinal neutrophil infiltration, and TNF $\alpha$ levels, and regulates levels of interleukins $[29,30]$. In IBD patients, the increase of ICAM-1 is involved in the massive recruitment of leukocytes to intestinal inflammatory sites, while the enhancement of $\mathrm{Cl}-2$ can induce the decrease and/or redistribution of epithelial tight junction proteins, leading to cytokine level increases and barrier dysfunction [16,92-94]. For this, TNF $\alpha$, by up-regulating ICAM- 1 and $\mathrm{Cl}-2$, contributes to exacerbating the inflammatory state and altering the epithelial barrier function. The natural tocopherols and semi-synthetic tocopheryl sulfur containing derivatives used in this study can mitigate the effect of TNF $\alpha$, a cytokine with a key role in the chronic intestinal inflammation that characterizes IBD, by preventing the oxidative stress and the up-regulation of ICAM- 1 and $\mathrm{Cl}-2$. 


\section{Conclusions}

This study shows, for the first time, that natural tocopherols, $\alpha$-Toc and $\delta$-Toc, and, even more efficiently, semi-synthetic $\delta$-tocopheryl sulfide and disulfide, $\left(\delta-T_{0}\right)_{2} S$ and $(\delta$ Toc) ${ }_{2} \mathrm{~S}_{2}$, prevent oxidative stress and ICAM- 1 and $\mathrm{Cl}-2$ expression up-regulation, in TNF $\alpha$ stimulated HT29 cells, by their antioxidant properties. This is particularly evident for ICAM-1, because of the presence of a strong relationship between ICAM-1 expression and intracellular redox state. Data obtained clearly indicate that the effect of $\alpha$-Toc and $\delta$-Toc, and $(\delta-T o c)_{2} S$ and $(\delta-T o c)_{2} S_{2}$, is not related to their well-known peroxyl radical scavenger ability. Conversely, TNF $\alpha$-induced $\mathrm{Cl}-2$ expression is due to redox- and nonredox-dependent mechanisms, and the two tocopherols, as well as the semi-synthetic $\delta$-tocopheryl sulfide and disulfide tested, are able to inhibit both mechanisms involved. In any of the registered effects, $(\delta-T o c)_{2} S$ and $\left(\delta-T_{0}\right)_{2} S_{2}$ demonstrated that both their tocopheryl units participate in the biological effect, having an activity similar or better than that of $\alpha$-Toc and $\delta$-Toc used in doubled molar concentration (Figure 6).

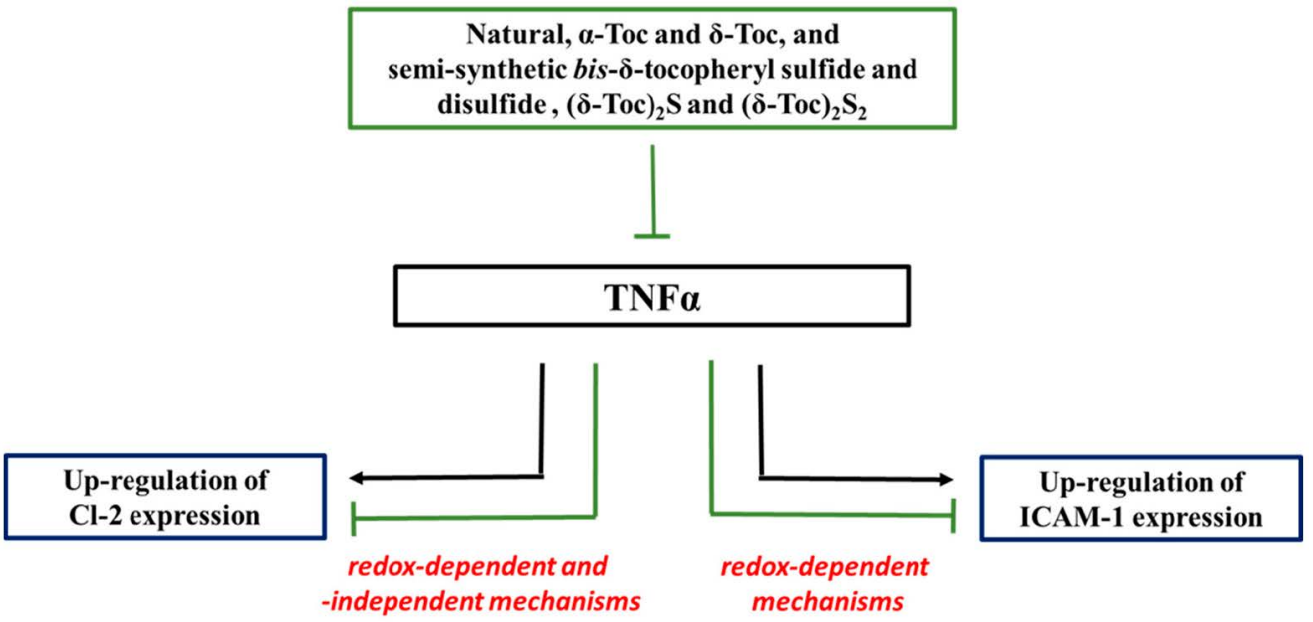

Figure 6. Schematic diagram illustrating the role of natural, $\alpha$-Toc, $\delta$-Toc, and semi-synthetic $(\delta \text {-Toc })_{2} S$ and $(\delta-T o c)_{2} S_{2}$ on TNF $\alpha$-induced ICAM- 1 and Cl-2 expression in HT2 2 cells. TNF $\alpha$ up-regulates ICAM-1 expression by redox-regulated mechanisms, and $\mathrm{Cl}-2$ expression by redoxand non-redox-regulated mechanisms. Natural tocopherols and semi-synthetic $\delta$-tocopheryl sulfide and disulfide inhibit both these mechanisms and prevent the up-regulation of ICAM-1 and Cl-2 expression.

We hope that in due course the additional investigations in our laboratories can confirm the beneficial role of $(\delta-T o c){ }_{2} S$ and $(\delta-T o c)_{2} S_{2}$ in the intestinal inflammatory diseases, in which are present high levels of TNF $\alpha$.

Author Contributions: Conceptualization, S.M., T.I.; Methodology, I.F., V.D., K.V., C.A.; Validation, T.I., S.M. and C.V.; Formal analysis. C.V., M.S. and I.F.; Investigation, V.D., I.F., K.V. and C.A.; Resources, T.I., S.M. and M.S.; Data Curation T.I., S.M. and C.A.; Writing-Original Draft Preparation T.I. and S.M.; Writing—Review and editing T.I., S.M. and V.D.; Funding acquisition T.I. and S.M. All authors have read and agreed to the published version of the manuscript.

Funding: This study was supported by grants from Ministero dell'Istruzione, dell'Università e della Ricerca (RICATEN20) to T.I. and S.M., S.M., C.V., and K.V. thank MIUR-Italy ("Progetto Dipartimenti di Eccellenza 2018-2022" allocated to Department of Chemistry "Ugo Schiff”, University of Florence, Italy).

Institutional Review Board Statement: Not Applicable.

Informed Consent Statement: Not Applicable.

Data Availability Statement: Not Applicable. 
Conflicts of Interest: The authors declare no conflict of interest.

\section{References}

1. Azzi, A.; Stocker, A. Vitamin E: Non-Antioxidant roles. Prog. Lipid Res. 2000, 39, 231-255. [CrossRef]

2. Rizvi, S.; Raza, S.T.; Ahmed, F.; Ahmad, A.; Abbas, S.; Mahdi, F. The role of vitamin e in human health and some diseases. Sultan Qaboos Univ. Med. J. 2014, 14, e157-e165. [PubMed]

3. Sookwong, P.; Nakagawa, K.; Yamaguchi, Y.; Miyazawa, T.; Kato, S.; Kimura, F.; Miyazawa, T. Tocotrienol distribution in foods: Estimation of daily tocotrienol intake of Japanese population. J. Agric. Food Chem. 2010, 58, 3350-3355. [CrossRef] [PubMed]

4. Howard, A.C.; McNeil, A.K.; McNeil, P.L. Promotion of plasma membrane repair by vitamin E. Nat. Commun. 2011, 2, 597. [CrossRef]

5. Zhazykbayeva, S.; Pabel, S.; Mügge, A.; Sossalla, S.; Hamdani, N. The molecular mechanisms associated with the physiological responses to inflammation and oxidative stress in cardiovascular diseases. Biophys. Rev. 2020, 12, 947-968. [CrossRef]

6. Oliveira, S.; Tamaeh Monteiro, A.; Silva, S.; Matafome, P. Curcumin derivatives for Type 2 Diabetes management and prevention of complications. Arch. Pharm. Res. 2020, 43, 567-581. [CrossRef]

7. Poznyak, A.V.; Melnichenko, A.A.; Wetzker, R.; Gerasimova, E.V.; Orekhov, A.N. NLPR3 Inflammasomes and Their Significance for Atherosclerosis. Biomedicines 2020, 8, 205. [CrossRef]

8. Ramani, S.; Pathak, A.; Dalal, V.; Paul, P.; Biswas, S. Oxidative Stress in Autoimmune Diseases: An Under Dealt Malice. Curr. Protein Pept. Sci. 2020, 21, 611-624. [CrossRef]

9. Bhattacharyya, A.; Chattopadhyay, R.; Mitra, S.; Crowe, S.E. Oxidative stress: An essential factor in the pathogenesis of gastrointestinal mucosal diseases. Physiol. Rev. 2014, 94, 329-354. [CrossRef]

10. Packiriswamy, N.; Coulson, K.F.; Holcombe, S.J.; Sordillo, L.M. Oxidative stress-induced mitochondrial dysfunction in a normal colon epithelial cell line. World J. Gastroenterol. 2017, 23, 3427-3439. [CrossRef]

11. Rao, R. Oxidative stress-induced disruption of epithelial and endothelial tight junctions. Front. Biosci. 2008, 13, 7210-7226. [CrossRef] [PubMed]

12. Oshima, T.; Miwa, H. Gastrointestinal mucosal barrier function and diseases. J. Gastroenterol. 2016, 51, 768-778. [CrossRef] [PubMed]

13. Zhu, L.; Han, J.; Li, L.; Wang, Y.; Li, Y.; Zhang, S. Claudin Family Participates in the Pathogenesis of Inflammatory Bowel Diseases and Colitis-Associated Colorectal Cancer. Front. Immunol. 2019, 10, 1441. [CrossRef] [PubMed]

14. Ghosh, S.; Panaccione, R. Anti-adhesion molecule therapy for inflammatory bowel disease. Therap. Adv. Gastroenterol. 2010, 3 , 239-258. [CrossRef]

15. Sumagin, R.; Brazil, J.C.; Nava, P.; Nishio, H.; Alam, A.; Luissint, A.C.; Weber, D.A.; Neish, A.S.; Nusrat, A.; Parkos, C.A. Neutrophil interactions with epithelial-expressed ICAM-1 enhances intestinal mucosal wound healing. Mucosal. Immunol. 2016, 9, 1151-1162. [CrossRef]

16. Vainer, B.; Nielsen, O.H.; Horn, T. Comparative studies of the colonic in situ expression of intercellular adhesion molecules (ICAM-1, -2, and -3), beta2 integrins (LFA-1, Mac-1, and p150,95), and PECAM-1 in ulcerative colitis and Crohn's disease. Am. J. Surg. Pathol. 2000, 24, 1115-1124. [CrossRef]

17. Biasi, F.; Leonarduzzi, G.; Oteiza, P.I.; Poli, G. Inflammatory bowel disease: Mechanisms, redox considerations, and therapeutic targets. Antioxid. Redox Signal. 2013, 19, 1711-1747. [CrossRef]

18. Thapa, D.; Lee, J.S.; Park, M.A.; Cho, M.Y.; Park, Y.J.; Choi, H.G.; Jeong, T.C.; Kim, J.A. Inhibitory effects of clotrimazole on TNF-alpha-induced adhesion molecule expression and angiogenesis. Arch. Pharm. Res. 2009, 32, 593-603. [CrossRef]

19. Amoozadeh, Y.; Dan, Q.; Xiao, J.; Waheed, F.; Szászi, K. Tumor necrosis factor- $\alpha$ induces a biphasic change in claudin-2 expression in tubular epithelial cells: Role in barrier functions. Am. J. Physiol. Cell Physiol. 2015, 309, C38-C50. [CrossRef]

20. Liu, F.; Cottrell, J.J.; Furness, J.B.; Rivera, L.R.; Kelly, F.W.; Wijesiriwardana, U.; Pustovit, R.V.; Fothergill, L.J.; Bravo, D.M.; Celi, P.; et al. Selenium and vitamin $\mathrm{E}$ together improve intestinal epithelial barrier function and alleviate oxidative stress in heat-stressed pigs. Exp. Physiol. 2016, 101, 801-810. [CrossRef]

21. Sun, Y.; Zhang, J.; Song, W.; Shan, A. Vitamin E alleviates phoxim-induced toxic effects on intestinal oxidative stress, barrier function, and morphological changes in rats. Environ. Sci. Pollut. Res. Int. 2018, 25, 26682-26692. [CrossRef] [PubMed]

22. Devaraj, S.; Jialal, I. Low-density lipoprotein postsecretory modification, monocyte function, and circulating adhesion molecules in type 2 diabetic patients with and without macrovascular complications: The effect of alpha-tocopherol supplementation. Circulation 2000, 102, 191-196. [CrossRef] [PubMed]

23. Gan, Y.L.; Fu, J.Y.; Lai, O.M.; Chew, B.H.; Yuen, K.H.; Teng, K.T.; Nesaretnam, K.; Selvaduray, K.R.; Meganathan, P. Effect of palm-based tocotrienols and tocopherol mixture supplementation on platelet aggregation in subjects with metabolic syndrome: A randomised controlled trial. Sci. Rep. 2017, 7, 11542. [CrossRef] [PubMed]

24. Sesso, H.D.; Buring, J.E.; Christen, W.G.; Kurth, T.; Belanger, C.; MacFadyen, J.; Bubes, V.; Manson, J.E.; Glynn, R.J.; Gaziano, J.M Vitamins $\mathrm{E}$ and $\mathrm{C}$ in the prevention of cardiovascular disease in men: The Physicians' Health Study II randomized controlled trial. JAMA 2008, 300, 2123-2133. [CrossRef]

25. Takahashi, S.; Takeshita, K.; Seeni, A.; Sugiura, S.; Tang, M.; Sato, S.; Kuriyama, H.; Nakadate, M.; Abe, K.; Maeno, Y.; et al. Suppression of prostate cancer in a transgenic rat model via gamma-tocopherol activation of caspase signalling. Prostate 2009, 69, 644-651. [CrossRef] 
26. Kono, N.; Ohto, U.; Hiramatsu, T.; Urabe, M.; Uchida, Y.; Satow, Y.; Arai, H. Impaired $\alpha$-TTP-PIPs interaction underlies familial vitamin E deficiency. Science 2013, 340, 1106-1110. [CrossRef]

27. Mangialasche, F.; Westman, E.; Kivipelto, M.; Muehlboeck, J.S.; Cecchetti, R.; Baglioni, M.; Tarducci, R.; Gobbi, G.; Floridi, P.; Soininen, H.; et al. Classification and prediction of clinical diagnosis of Alzheimer's disease based on MRI and plasma measures of $\alpha-/ \gamma$-tocotrienols and $\gamma$-tocopherol. J. Intern. Med. 2013, 273, 602-621. [CrossRef]

28. Fabisiak, N.; Fabisiak, A.; Watala, C.; Fichna, J. Fat-soluble Vitamin Deficiencies and Inflammatory Bowel Disease: Systematic Review and Meta-Analysis. J. Clin. Gastroenterol. 2017, 51, 878-889. [CrossRef]

29. Isozaki, Y.; Yoshida, N.; Kuroda, M.; Takagi, T.; Handa, O.; Kokura, S.; Ichikawa, H.; Naito, Y.; Okanoue, T.; Yoshikawa, T. Effect of a novel water-soluble vitamin E derivative as a cure for TNBS-induced colitis in rats. Int. J. Mol. Med. 2006, 17, 497-502. [CrossRef]

30. Hiratsuka, T.; Inomata, M.; Hagiwara, S.; Kono, Y.; Shiraishi, N.; Noguchi, T.; Kitano, S. Bolus injection of newly synthesized vitamin E derivative ETS-GS for the treatment of acute severe ulcerative colitis in a mouse model. New vitamin E derivative for acute severe UC. Int. J. Colorectal. Dis. 2013, 28, 305-311. [CrossRef]

31. Wu, H.; Liu, S.; Gong, J.; Liu, J.; Zhang, Q.; Leng, X.; Zhang, N.; Li, Y. VCPA, a novel synthetic derivative of $\alpha$-tocopheryl succinate, sensitizes human gastric cancer to doxorubicin-induced apoptosis via ROS-dependent mitochondrial dysfunction. Cancer Lett. 2017, 393, 22-32. [CrossRef] [PubMed]

32. Kono, Y.; Inomata, M.; Hagiwara, S.; Shiraishi, N.; Noguchi, T.; Kitano, S. A newly synthetic vitamin E derivative, E-Ant-S-GS, attenuates lung injury caused by cecal ligation and puncture-induced sepsis in rats. Surgery 2012, 151, 420-426. [CrossRef] [PubMed]

33. Caccamo, D.; Campisi, A.; Marini, H.; Adamo, E.B.; Li Volti, G.; Squadrito, F.; Ientile, R. Glutamate promotes NF-kappaB pathway in primary astrocytes: Protective effects of IRFI 016, a synthetic vitamin E analogue. Exp. Neurol. 2005, 193, 377-383. [CrossRef] [PubMed]

34. Viglianisi, C.; Vasa, K.; Tanini, D.; Capperucci, A.; Amorati, R.; Valgimigli, L.; Baschieri, A.; Menichetti, S. Ditocopheryl sulfides and disulfides: Synthesis and antioxidant profile. Chem. Eur. J. 2019, 25, 9108-9116. [CrossRef]

35. Wang, J.; Li, M.; Zhang, W.; Gu, A.; Dong, J.; Li, J.; Shan, A. Protective Effect of N-Acetylcysteine against Oxidative Stress Induced by Zearalenone via Mitochondrial Apoptosis Pathway in SIEC02. Cells Toxins 2018, 10, 407. [CrossRef] [PubMed]

36. Elisia, I.; Kitts, D.D. Tocopherol isoforms ( $\alpha-, \gamma-$, and $\delta$-) show distinct capacities to control Nrf- 2 and NfkB signaling pathways that modulate inflammatory response in Caco-2 intestinal cells. Mol. Cell Biochem. 2015, 404, 123-131. [CrossRef]

37. Luan, S.; Muhayimana, S.; Xu, J.; Zhang, X.; Xiao, C.; Huang, Q. The effect of $\alpha$-tocopherol and dithiothreitol in ameliorating emamectin benzoate cytotoxicity in human K562 cells involving the modulation of ROS accumulation and NF- $\mathrm{kB}$ signaling. Ecotoxicol. Environ. Saf. 2019, 167, 114-121. [CrossRef]

38. Viglianisi, C.; Bonardi, C.; Ermini, E.; Capperucci, A.; Menichetti, S.; Tanini, D. Selenosilane-promoted selective mild transformation of $N$-thiophthalimides into symmetric disulfides. Synthesis 2019, 51, 1819-1824. [CrossRef]

39. Catarzi, S.; Romagnoli, C.; Marcucci, G.; Favilli, F.; Iantomasi, T.; Vincenzini, M.T. Redox regulation of ERK1/2 activation induced by sphingosine 1-phosphate in fibroblasts: Involvement of NADPH oxidase and platelet-derived growth factor receptor. Biochim. Biophys. Acta 2011, 1810, 446-456. [CrossRef]

40. Smith, P.K.; Krohn, R.I.; Hermanson, G.T.; Mallia, A.K.; Gartner, F.H.; Provenzano, M.D.; Fujimoto, E.K.; Goeke, N.M.; Olson, B.J.; Klenk, D.C. Measurement of protein using bicinchoninic acid. Anal. Biochem. 1985, 150, 76-85. [CrossRef]

41. Weinberg, R.B.; Vander Werken, B.S.; Anderson, R.A.; Stegner, J.E.; Thomas, M.J. Pro-Oxidant Effect of Vitamin E in Cigarette Smokers Consuming a High Polyunsaturated Fat Diet. Arterioscler. Thromb. Vasc. Biol 2001, 21, 1029-1033. [CrossRef]

42. Pearson, P.; Lewis, S.A.; Britton, J.; Young, I.S.; Fogarthy, A. The Pro-Oxidant Activity of High-Dose Vitamin E Supplements in Vivo. BioDrugs 2006, 20, 271-273. [CrossRef]

43. Winterbone, M.S.; Sampson, M.J.; Saha, S.; Hughes, J.C.; Hughes, D.A. Pro-oxidant effect of $\alpha$-tocopherol in patients with Type 2 Diabetes after an oral glucose tolerance test-A randomised controlled trial. Cardiovasc Diabetol. 2007, 6, 8. [CrossRef] [PubMed]

44. Nadeem, N.; Woodside, J.V.; Kelly, S.; Allister, R.; Young, I.S.; McEnemy, J. The two faces of $\alpha$ - and $\gamma$-tocopherols: An in vitro and ex vivo investigation into VLDL, LDL and HDL oxidation. J. Nutr. Biochem. 2012, 23, 845-851. [CrossRef] [PubMed]

45. Dubbs, M.D.; Gupta, R.B. Solubility of Vitamin E (-Tocopherol) and Vitamin K3 (Menadione) in Ethanol-Water Mixture. J. Chem. Eng. Data 1998, 43, 590-591. [CrossRef]

46. Burton, G.W.; Ingold, K.U. Autoxidation of biological molecules. 1. Antioxidant activity of vitamin E and related chain-breaking phenolic antioxidants in vitro. J. Am. Chem. Soc. 1981, 103, 6472-6477. [CrossRef]

47. Böhm, V. Vitamin E. Antioxidants 2018, 7, 44. [CrossRef]

48. Viglianisi, C.; Menichetti, S. Chain Breaking Antioxidant Activity of Heavy (S, Se, Te) Chalcogens Substituted Polyphenols. Antioxidants 2019, 8, 487. [CrossRef] [PubMed]

49. Domazetovic, V.; Fontani, F.; Tanini, D.; D’Esopo, V.; Viglianisi, C.; Marcucci, G.; Panzella, L.; Napolitano, A.; Capperucci, A.; Menichetti, S.; et al. Protective role of benzoselenophene derivatives of resveratrol in the induced oxidative stress in intestinal myofibroblasts and osteocytes. Chem. Biol. Interact. 2017, 275, 13-21. [CrossRef]

50. Menichetti, S.; Amorati, R.; Meoni, V.; Tofani, L.; Caminati, G.; Viglianisi, C. Role of Noncovalent Sulfur.Oxygen Interactions in Phenoxyl Radical Stabilization: Synthesis of Super Tocopherol-like Antioxidants. Org. Lett. 2016, 18, 5464-5467. [CrossRef] 
51. Viglianisi, C.; Di Pietro, L.; Amorati, R.; Menichetti, S. A straightforward route to potent phenolic chain breaking antioxidants by acid promoted transposition of 1,4-benzo[b]oxathiines to dihydrobenzo[b]thiophenes. Chem. Eur. J. 2015, 21, 16639-16645. [CrossRef] [PubMed]

52. Tanini, D.; Panzella, L.; Amorati, R.; Capperucci, A.; Napolitano, A.; Menichetti, S.; D'Ischia, M. Resveratrol-Based Benzoselenophenes with Enhanced Antioxidant and Chain Breaking Capacity. Org. Biomol. Chem. 2015, 13, 5757-5764. [CrossRef] [PubMed]

53. Menichetti, S.; Amorati, R.; Pedulli, G.F.; Bartolozzi, M.G.; Viglianisi, C. Optimization of the Antioxidant Activity of Hydroxy Substituted 4-Thiaflavanes: A Proof-of-Concept Study. Chem. Eur. J. 2011, 17, 12396-12404.

54. Menichetti, S.; Amorati, R.; Pedulli, G.F.; Attanasi, A.O.; Favi, G.; Viglianisi, C. Amphiphilic antioxidants from "cashew nut shell liquid" (CNSL) waste". Org. Biomol. Chem. 2011, 9, 1352-1355.

55. Amorati, R.; Catarzi, F.; Menichetti, S.; Pedulli, G.F.; Viglianisi, C. Effect of ortho-SR Groups on O-H Bond Strength and H-Atom Donating Ability of Phenols: A Possible Role for the Tyr-Cys Link in Galactose Oxidase Active Site? J. Am. Chem. Soc. 2008, 130, 237-244. [CrossRef]

56. Amorati, R.; Cavalli, A.; Fumo, M.G.; Masetti, M.; Menichetti, S.; Pagliuca, C.; Pedulli, G.F.; Viglianisi, C. Kinetic and Thermochemical Study of the Antioxidant Activity of Sulfur Containing Analogues of Vitamin E. Chem. Eur. J. 2007, 13, 8223-8230. [CrossRef]

57. Amorati, R.; Fumo, M.G.; Menichetti, S.; Mugnaini, V.; Pedulli, G.F. Electronic and hydrogen bonding effects on the chain-breaking activity of sulfur containing phenolic antioxidants. J. Org. Chem. 2006, 71, 6325-6332. [CrossRef]

58. Lodovici, M.; Menichetti, S.; Viglianisi, C.; Caldini, S.; Giuliani, E. Polyhydroxylated 4-Thiaflavans as Multipotent Antioxidants: Protective Effect on Oxidative DNA Damage in vitro". Bioorg. Med. Chem. Lett. 2006, 16, 1957-1960. [CrossRef]

59. Menichetti, S.; Aversa, M.C.; Cimino, F.; Contini, A.; Tomaino, A.; Viglianisi, C. Synthesis and 'double-faced' antioxidant activity of polyhydroxylated 4-thiaflavans. Org. Biomol. Chem. 2005, 3, 3066-3072. [CrossRef] [PubMed]

60. Capozzi, G.; Lo Nostro, P.; Menichetti, S.; Nativi, C.; Sarri, P. Easy synthesis of polyphenolic 4-thiaflavans with a "double-faced" antioxidant activity. Chem. Commun. 2001, 6, 551-552. [CrossRef]

61. Wagar, L.E.; Champagne, C.P.; Buckley, N.D.; Raymond, Y.; Green-Johnson, J.M. Immunomodulatory properties of fermented soy and dairy milks prepared with lactic acid bacteria. J. Food Sci. 2009, 74, M423-M430. [CrossRef] [PubMed]

62. Ferguson, L.R.; Zhu, S.; Harris, P.J. Antioxidant and antigenotoxic effects of plant cell wall hydroxycinnamic acids in cultured HT-29 cells. Mol. Nutr. Food Res. 2005, 49, 585-593. [CrossRef] [PubMed]

63. Dippold, W.; Wittig, B.; Schwaeble, W.; Mayet, W.; zum Büschenfelde, K.H.M. Expression of intercellular adhesion molecule 1 (ICAM-1, CD54) in colonic epithelial cells. Gut 1993, 34, 1593-1597. [CrossRef] [PubMed]

64. Amasheh, S.; Meiri, N.; Gitter, A.H.; Schöneberg, T.; Mankertz, J.; Schulzke, J.D.; Fromm, M. Claudin-2 expression induces cation-selective channels in tight junctions of epithelial cells. J. Cell Sci. 2002, 115, 4969-4976. [CrossRef] [PubMed]

65. Heller, F.; Florian, P.; Bojarski, C.; Richter, J.; Christ, M.; Hillenbrand, B.; Mankertz, J.; Gitter, A.H.; Bürgel, N.; Fromm, M.; et al. Interleukin-13 is the key effector Th2 cytokine in ulcerative colitis that affects epithelial tight junctions, apoptosis, and cell restitution. Gastroenterology 2005, 129, 550-564. [CrossRef] [PubMed]

66. Domazetovic, V.; Iantomasi, T.; Bonanomi, A.G.; Stio, M. Vitamin D regulates claudin-2 and claudin-4 expression in active ulcerative colitis by p-Stat-6 and Smad-7 signaling. Int. J. Colorectal Dis. 2020, 35, 1231-1242. [CrossRef] [PubMed]

67. Fontani, F.; Domazetovic, V.; Marcucci, T.; Vincenzini, M.T.; Iantomasi, T. Tumor Necrosis Factor-Alpha Up-Regulates ICAM-1 Expression and Release in Intestinal Myofibroblasts by Redox-Dependent and Independent Mechanisms. J. Cell Biochem. 2016, 117, 370-381. [CrossRef]

68. Domazetovic, V.; Bonanomi, A.G.; Stio, M.; Vincenzini, M.T.; Iantomasi, T. Resveratrol decreases TNF $\alpha$-induced ICAM-1 expression and release by Sirt-1-independent mechanism in intestinal myofibroblasts. Exp. Cell Res. 2019, 382, 111479. [CrossRef]

69. Sung, H.C.; Liu, C.W.; Hsiao, C.Y.; Lin, S.R.; Yu, I.S.; Lin, S.W.; Chiang, M.H.; Liang, C.J.; Pu, C.M.; Chen, Y.C.; et al. The effects of wild bitter gourd fruit extracts on ICAM-1 expression in pulmonary epithelial cells of C57BL/6J mice and microRNA-221/222 knockout mice: Involvement of the miR-221/-222/PI3K/AKT/NF-kB pathway. Phytomedicine 2018, 42, 90-99. [CrossRef]

70. Nishida, M.; Yoshida, M.; Nishiumi, S.; Furuse, M.; Azuma, T. Claudin-2 regulates colorectal inflammation via myosin light chain kinase-dependent signalling. Dig. Dis. Sci. 2013, 58, 1546-1559. [CrossRef]

71. Huang, W.C.; Dai, Y.W.; Peng, H.L.; Kang, C.W.; Kuo, C.Y.; Liou, C.J. Phloretin ameliorates chemokines and ICAM-1 expression via blocking of the NF-kB pathway in the TNF- $\alpha$-induced HaCaT human keratinocytes. Int. Immunopharmacol. 2015, 27, 32-37. [CrossRef] [PubMed]

72. Kurpios-Piec, D.; Grosicka-Maciagg, E.; Woźniak, K.; Kowalewski, C.; Kiernozek, E.; Szumiło, M.; Rahden-Staroń, I. Thiram activates NF-kappaB and enhances ICAM-1 expression in human microvascular endothelial HMEC-1 cells. Pestic. Biochem. Physiol. 2015, 118, 82-89. [CrossRef] [PubMed]

73. Lu, Y.; Li, L.; Zhang, J.W.; Zhong, X.Q.; Wei, J.A.; Han, L. Total polysaccharides of the Sijunzi decoction attenuate tumor necrosis factor- $\alpha$-induced damage to the barrier function of a Caco-2 cell monolayer via the nuclear factor- $\mathrm{kB}$-myosin light chain kinase-myosin light chain pathway. World J. Gastroenterol. 2018, 24, 2867-2877. [CrossRef] [PubMed]

74. Calfee-Mason, K.G.; Spear, B.T.; Glauert, H.P. Vitamin E inhibits hepatic NF-kappaB activation in rats administered the hepatic tumor promoter, phenobarbital. J. Nutr. 2002, 132, 3178-3185. [CrossRef] 
75. Yang, C.; Jiang, Q. Vitamin E $\delta$-tocotrienol inhibits TNF- $\alpha$-stimulated NF- $\mathrm{BB}$ activation by up-regulation of anti-inflammatory A20 via modulation of sphingolipid including elevation of intracellular dihydroceramides. J. Nutr. Biochem. 2019, 64, 101-109. [CrossRef]

76. Husain, K.; Francois, R.A.; Yamauchi, T.; Perez, M.; Sebti, S.M.; Malafa, M.P. Vitamin E $\delta$-tocotrienol augments the antitumor activity of gemcitabine and suppresses constitutive NF-кB activation in pancreatic cancer. Mol. Cancer Ther. 2011, 10, $2363-2372$. [CrossRef]

77. Crispen, P.L.; Uzzo, R.G.; Golovine, K.; Makhov, P.; Pollack, A.; Horwitz, E.M.; Greenberg, R.E.; Kolenko, V.M. Vitamin E succinate inhibits NF-kappaB and prevents the development of a metastatic phenotype in prostate cancer cells: Implications for chemoprevention. Prostate 2007, 67, 582-590. [CrossRef]

78. Chow, C.K. Biological functions and metabolic fate of vitamin E revisited. Biomed. Sci. 2004, 11, 295-302. [CrossRef]

79. Zingg, J.M. Vitamin E: Regulatory Role on Signal Transduction. IUBMB Life 2019, 71, 456-478. [CrossRef]

80. Mankertz, J.; Amasheh, M.; Krug, S.M.; Fromm, A.; Amasheh, S.; Hillenbrand, B.; Tavalali, S.; Fromm, M.; Schulzke, J.D. TNFalpha up-regulates claudin-2 expression in epithelial HT-29/B6 cells via phosphatidylinositol-3-kinase signalling. Cell Tissue Res. 2009, 336, 67-77. [CrossRef]

81. Luettig, J.; Rosenthal, R.; Lee, I.F.M.; Krug, S.M.; Schulzke, J.D. The ginger component 6-shogaol prevents TNF- $\alpha$-induced barrier loss via inhibition of PI3K/Akt and NF-kB signalling. Mol. Nutr. Food Res. 2016, 60, 2576-2586. [CrossRef] [PubMed]

82. Kim, S.G.; Kim, S.O. PKC downstream of Pl3-kinase regulates peroxynitrite formation for Nrf2-mediated GSTA2 induction. Arch. Pharm. Res. 2004, 27, 757-762. [CrossRef] [PubMed]

83. Tong, H.; Chen, W.; Steenbergen, C.; Murphy, E. Ischemic preconditioning activates phosphatidylinositol-3-kinase upstream of protein. Circ. Res. 2000, 87, 309-315. [CrossRef] [PubMed]

84. Azzi, A.; Gysin, R.; Kempná, P.; Munteanu, A.; Negis, Y.; Villacorta, L.; Visarius, T.; Zingg, J.M. Vitamin E mediates cell signaling and regulation of gene expression. Ann. N. Y. Acad. Sci. 2004, 1031, 86-95. [CrossRef] [PubMed]

85. Breyer, I.; Azzi, A. Differential inhibition by alpha- and beta-tocopherol of human erythroleukemia cell adhesion: Role of integrins. Free Radic. Biol. Med. 2001, 30, 1381-1389. [CrossRef]

86. Tahir, M.; Foley, B.; Pate, G.; Crean, P.; Moore, D.; McCarroll, N.; Walsh, M. Impact of vitamin E and C supplementation on serum adhesion molecules in chronic degenerative aortic stenosis: A randomized controlled trial. Am. Heart J. 2005, 150, 302-306. [CrossRef] [PubMed]

87. Vignini, A.; Nanetti, L.; Moroni, C.; Testa, R.; Sirolla, C.; Marra, M.; Manfrini, S.; Fumelli, D.; Marcheselli, F.; Mazzanti, L.; et al. A study on the action of vitamin E supplementation on plasminogen activator inhibitor type 1 and platelet nitric oxide production in type 2 diabetic patients. Nutr. Metab. Cardiovasc. Dis. 2008, 18, 15-22. [CrossRef] [PubMed]

88. Heppner, F.L.; Roth, K.; Nitsch, R.N.; Hailer, P. Vitamin E induces ramification and downregulation of adhesion molecules in cultured microglial cells. Glia 1998, 22, 180-188. [CrossRef]

89. Catalán, U.; Fernández-Castillejo, S.; Pons, L.; Heras, M.; Aragonés, G.; Anglès, N.; Morelló, J.R.; Solà, R. Alpha-tocopherol and BAY 11-7082 reduce vascular cell adhesion molecule in human aortic endothelial cells. J. Vasc. Res. 2012, 49, 319-328. [CrossRef]

90. Song, Z.; Lv, J.; Sheikhahmadi, A.; Uerlings, J.; Everaert, N. Attenuating Effect of Zinc and Vitamin E on the Intestinal Oxidative Stress Induced by Silver Nanoparticles in Broiler Chickens. Biol. Trace Elem. Res. 2017, 180, 306-313. [CrossRef]

91. Liu, K.Y.; Nakatsu, C.H.; Jones-Hall, Y.; Kozik, A.; Jiang, Q. Vitamin E alpha- and gamma-tocopherol mitigate colitis, protect intestinal barrier function and modulate the gut microbiota in mice. Free Radic. Biol. Med. 2020, 163, 180-189. [CrossRef] [PubMed]

92. Zeissig, S.; Bürgel, N.; Günzel, D.; Richter, J.; Mankertz, J.; Wahnschaffe, U.; Kroesen, A.J.; Zeitz, M.; Fromm, M.; Schulzke, J.D. Changes in expression and distribution of claudin 2, 5 and 8 lead to discontinuous tight junctions and barrier dysfunction in active Crohn's disease. Gut 2007, 56, 61-72. [CrossRef] [PubMed]

93. Hubbard, A.K.; Rothlein, R. Intercellular adhesion molecule-1 (ICAM-1) expression and cell signaling cascades. Free Radic. Biol. Med. 2000, 28, 1379-1386. [CrossRef]

94. Amasheh, S.; Dullat, S.; Fromm, M.; Schulzke, J.D.; Buhr, H.J.; Kroesen, A.J. Inflamed pouch mucosa possesses altered tight junctions indicating recurrence of inflammatory bowel disease. Int. J. Colorectal Dis. 2009, 24, 1149-1156. [CrossRef] 